\title{
Manajemen Pembelajaran dalam Mengembangkan Kemampuan Sosial Anak Usia Dini
}

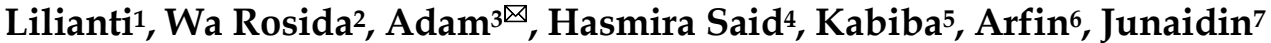 \\ Administrasi Pendidikan, Universitas Muhammadiyah Kendari $(1,2,5,6,7)$ \\ Pendidikan Guru Pendidikan Anak Usia Dini, Universitas Muhammadiyah Kendari(3) \\ Pendidikan Masyarakat/PNF, Universitas Muhammadiyah Kendari(4)
}

\begin{abstract}
Abstrak
Pengembangan kemampuan anak dalam bersosialisasi dapat dikembangkan melalui berbagai materi dan metode yang telah disediakan guru. Tujuan penelitian ini untuk mengetahui lebih lanjut mengenai manajemen pembelajaran dalam mengembangkan kemampuan sosial anak. Jenis penelitian yang digunakan dalam penelitian ini adalah deskriptif kualitatif. Data penelitian dikumpulkan melalui observasi, wawancara, dan dokumen. Data dianalisis menggunakan reduksi data, penyajian data, dan penarikan kesimpulan. Hasil penelitian ini menyimpulkan bahwa perencanaan pembelajaran dikembangkan sesuai ketersediaan sarana dan prasarana belajar yang dilakukan oleh guru taman kanak-kanak Amaliah Mandara Mendidoha di Desa Ululakara, pelaksanaan pembelajaran dilaksanakan dengan saling berinteraksi langsung antara guru dengan anak didik, sehingga anak memiliki semangat dalam proses belajarnya, evaluasi pembelajaran dilakukan dengan mengamati semua aspek perkembangan peserta didik dimulai pada saat anak bermain, bergaul, maupun berkomunikasi terhadap orang lain dengan mencatat setiap tingkah laku anak sesuai dengan apa yang dilihat dan didengar dalam proses pembelajaran berlangsung maupun di luar kegiatan pembelajaran.
\end{abstract}

Kata Kunci: manajemen pembelajaran;anak usia dini; kemampuan sosial.

\begin{abstract}
The development of children's abilities in socializing can be developed through various materials and methods that have been provided by the teacher. The purpose of this study is to find out more about learning management in developing children's social skills. This type of research used in this research is descriptive qualitative. The research data were collected through observation, interviews, and documents. Data analysis using data reduction, data presentation, and withdrawal. The results of the study concluded that the learning planning developed was in accordance with the information and learning infrastructure carried out by Amaliah Mandara Mendidoha kindergarten teachers in Ululakara Village, the implementation of learning was carried out by directly competing with each other between teachers and students, so that children had enthusiasm in the learning process. Learning evaluation is carried out with the help of all aspects of student development starting when children play, socialize, and communicate with others with notes that each child's notes are in accordance with what is seen and heard in the learning process taking place and outside of learning activities.
\end{abstract}

Keywords: learning management; early childhood; social skills.

Copyright (c) 2021 Lilianti, Wa Rosida, Adam, Hasmira Said, Kabiba, Arfin, Junaidin

$\triangle$ Corresponding author :

Email Address : adamin.kotakendari2015@gmail.com (Kendari, Sulawesi Tenggara, Indonesia)

Received 16 February 2021, Accepted 26 February 2021, Published 5 March 2021 


\section{PENDAHULUAN}

Usia dini merupakan masa kritis bagi pembentukan karakter dan masa ini disebut juga dengan periode emas (golden age) dimana pada masa ini kemampuan otak anak berkembang sangat cepat hingga 80\%(Suharni, 2019). Konsep "golden age" diperkuat oleh fakta yang ditemukan oleh ahli Neurologi yang menyatakan bahwa pada saat lahir otak bayi mengandung 100-200 miliar neuron atau sel saraf yang siap melakukan sambungan antar sel(Suharti, 2018). Hal ini menjadi dasar utama untuk meletakkan dasar-dasar pengembangan yang dimiliki anak. Sebagaimana pada tahap perkembangan anak terdapat enam aspek perkembangan yakni perkembangan nilai moral dan agama, perkembangan fisik motorik, perkembangan bahasa, perkembangan sosial emosional, perkembangan kognitif dan aspek perkembangan seni (Dewi, 2017). Seorang anak manusia yang dilahirkan ke dunia ini sudah dibekali dengan pembawaan, bakat, atau potensi yang sangat penting dalam proses perkembangan berikutnya. Namun demikian, lingkungan yang berada di sekitar sang anak dibesarkan, termasuk dalam hal ini adalah lingkungan pendidikan juga turut memberikan andil dan pengaruh dalam perkembangan anak (Akhmad, 2010). Anak usia dini yang sudah dapat sekolah baik di PAUD formal maupun informal dalamperkembangan kemampuan dan kecerdasannya dibantu oleh guru (Kusbudiah, 2014). Peran guru dan orang tua sangat penting dalam merangsang dan memfasilitasi seluruh aspek perkembangan tersebut (Munawaroh, 2017).

Lingkungan perlu dirancang sedemikian rupa agar dapat mengembangkan dan menyempurnakan apa yang dibawa anak sejak lahir. Rancangan itu dapat dilakukan di rumah, sekolah, atau di mana saja. Di sekolah, yaitu TK (Taman Kanak-Kanak), RA (Raudhatul Athfal), atau KB (Kelompok Bermain), rancangan itu sebagai rancangan pembelajaran atau pelaksanaan program. Sebagaimana dalam Undang-Undang Nomor 20 Tahun 2003 Pasal 28, menyatakan bahwa "Pendidikan anak usia dini pada jalur pendidikan formal berbentuk Taman Kanak-kanak (TK), Raudhatul Athfal (RA), atau bentuk lain yang sederajat". PAUD pada jalur pendidikan non-formal berbentuk Kelompok Bermain (KB), Taman Penitipan Anak (TPA). PAUD pada jalur pendidikan informal berbentuk pendidikan keluarga dan yang diselenggarakan oleh lingkungan masyarakat. Oleh karena itu, PAUD menjadi sangat penting mengingat potensi kecerdasan dan dasar-dasar perilaku seseorang terbentuk pada rentang usia ini (Rozalena, 2017).

Generasi yang berkualitas adalah harapan masyarakat, masyarakat sangat mengharapkan adanya pendidikan yang memadai untuk putra putrinya, terlebih pada saat mereka masih berada dalam usia dini(Rozalena, 2017). Pentingnya PAUD telah menjadi perhatianInternasional. Maka mau tidak mau kita harus memacu untuk meningkatkan kualitas sumber daya manusia sedini mungkin, terutama perlu disadari tentang pentingnya Pendidikan Anak Usia Dini bagi setiap keluarga (Zubaidi, 2020). Untuk itu, sistem kegiatan pembelajaran PAUD harus dirancang secara khusus melalui metode bermain sambil belajar (Dewi, 2017).

Adapun dasar untuk melatih anak dalam mengembangkan kemampuan sosialnya dapat dimulai dengan memberi contoh terhadap hal-hal kecil, misalnya meminta maaf apabila telah melakukan kesalahan, mengucapkan permisi ketika akan melewati kerumunan orangorang yang sedang duduk dan berjalan dengan sedikit menunduk, dan mengucapkan terima kasih ketika diberi sesuatu oleh orang lain atau ada orang lain yang mengucapkan selamat karena kita mendapat kesenangan dan ucapan turut berduka cita ketika kita tertimpa musibah.

Selain di lingkungan keluarga, pengembangan kemampuan sosial anak usia dini juga dapat dilakukan di sekolah. Dalam hal ini, guru sebagai subjek utama harus mampu memberikan bimbingan dalam rangka membantu anak memahami alasan tentang diterapkannya aturan seperti keharusan memelihara ketertiban di dalam kelas, larangan masuk atau keluar dengan saling mendahului, membantu mereka membiasakan untuk memelihara persahabatan, kerja sama, saling membantu, dan saling menghargai atau 
menghormati. Guru juga dapat memberikan informasi kepada anak tentang adanya keragaman budaya, suku, dan agama di masyarakat atau dikalangan anak sendiri dan perlunya saling menghormati di antara mereka (Ahmad Susanto, 2012: 178).

Sebuah penelitian yang dilakukan oleh Ahmad Denico (2018) di KB Cerdas Kabupaten Rokan Hilir ditemukan bahwa manajemen pembelajaran meliputi perencanaan pembelajaran, pelaksanaan pembelajaran dan evaluasi pembelajaran. Perencanaan pembelajaran dilakukan sebelum ajaran baru dimulai dan perencanaan ini berisikan perencanaan semesteran, perencanaan mingguan, dan perencanaan harian yang dijadikan sebagai panduan dalam mempersiapkan kegiatan pembelajaran sesuai dengan perkembangan anak telah direncanakan dengan baik. Pada tahap pelaksanaan pembelajaran dilaksanakan sesuai rencana yang telah disusun yang terdiri dari pembukaan, kegiatan inti, dan penutup. Penilaian pembelajaran dilakukan melalui pengamatan, penugasan, unjuk kerja, pencatatan anekdot, percakapan, laporan orang tua, dokumentasi hasil karya anak serta deskripsi profil anak. Hal ini didukung dengan penelitian yang dilakukan oleh (Dyah Fifin Fatimah dkk, 2016) yang menyimpulkan bahwa dalam setiap kegiatan pembelajaran selalu dilaksanakan perencanaan, setelah itu melakukan pengorganisasian dengan berkomunikasi dan menjalin kerjasama dengan berbagai pihak. Sedangkan untuk pelaksanaannya selalu menyisipkan materi tentang pendidikan Agama. Begitupun juga dengan pembelajaran selalu dilakukan PAUD Ceria pada setiap harinya guna mengetahui proses pembelajaran telah tercapai sesuai dengan tujuan yang telah dibuat oleh sekolah PAUD ceria.

Merujuk pada hasil penelitian yang telah dijelaskan tersebut, maka dalam mengelola pembelajaran perlu dirancang dengan baik sehingga pengembangan kemampuan anak dalam bersosialisasi melalui implementasi pembelajaran dapat dikembangkan melalui berbagai materi yang telah disediakan guru serta metode-metode pembelajaran seperti metode pembiasaan dan sosiodrama yang dapat menarik perhatian anak untuk mengikuti kegiatan pembelajaran dengan baik. Berdasarkan data yang diperoleh Di TK Amaliah Mandara Mendidoha di Desa Ululakara penulis melihat bahwa kemampuan sosial peserta didik belum dapat berkembang secara maksimal, misalnya anak kurang disiplin baik ketika berangkat sekolah maupun dalam kegiatan pembelajaran. Hal ini bisa dimaklumi, akan tetapi berdampak tidak baik bagi perkembangan sosialnya jika anak tidak dilatih berdisiplin sejak dini dalam melakukan segala sesuatu. Kemudian anak yang suka mengganggu temannya, saling mengejek, susah diatur dan bertingkah semaunya sendiri. Selain itu, ada pula anak yang menunjukkan sikap pemalu dalam bermain, hal itu bisa saja disebabkan oleh perasaan takut kalau tidak diterima oleh kelompok bermainnya. Untuk itu peneliti tertarik untuk melakukan penelitian tentang bagaimanakah manajemen pembelajaran dalam mengembangkan kemampuan sosial anak usia dini di TK Amaliah Mandara Mendidoha Desa Ululakara?, dengan tujuan untuk mengetahui manajemen pembelajaran dalam mengembangkan kemampuan sosial anak usia dini di TK Amaliah Mandara Mendidohan Desa Ululakara.

\section{METODOLOGI}

Jenis penelitian yang digunakan dalam penelitian ini adalah deskriptif kualitatif. alasan dipilihnya metode tersebut karenadalam penelitian ini peneliti mengungkap data berkaitan dengan manajemen pembelajaran dalam mengembangkan kemampuan sosial anak usia dini di TK Amaliah Mandara Mendidoha yang diambil langsung dari lokasi penelitian melalui pengamatan pada kegiatan-kegiatan yang dilaksanakan dan dokumen-dokumen yang dimiliki.Sebagaimana Sugiyono(2017)mengatakan bahwa metode penelitian kualitatif merupakan salah satu jenis penelitian yang spesifikasinya adalah sistematis, terencana dan terstruktur dengan jenis sejak awal hingga pembuatan desain penelitiannya. Analisis data yang digunakan dalam penelitian ini adalah berdasarkan analisis interaktif sebagaimana dikemukakan oleh Miles, M. B, Huberman, A. M, dan Saldana, tahun 2014dalam (Usman \& 
Akbar, 2017) analisis tersebut terdiri dari tiga kegiatan yang saling berinteraksi yakni kondensasi data, penyajian data, dan penarikan kesimpulan seperti yang terdapat pada gambar 1 .

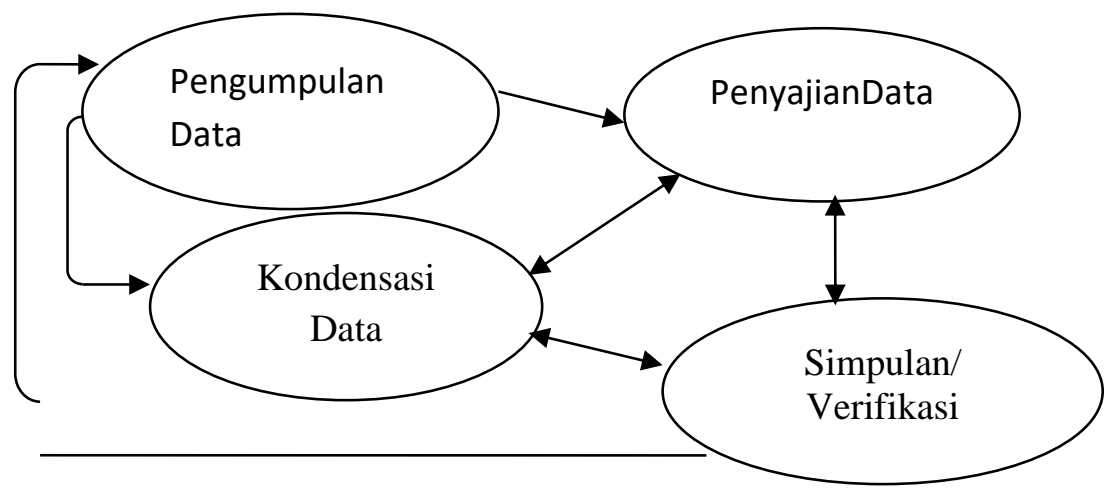

Gambar 1. Model Analisis Interaktif

(Diadaptasi dari metodologi penelitian sosial, (Usman \& Akbar, 2017: 136)

Pada tahap pertama, peneliti terlebih dahulu menjalin keakraban dengan informan yakni kepala TK, guru kelas TK, dan staf administrasi TK Amaliah Mandara Mendidoha Desa Ululakara guna untuk mengumpulkan data dengan menggunakan teknik pengumpulan data antara lain:

Teknik observasi yaitu peneliti melakukan pengamatan secara langsung dan terstruktur serta sistematis. Kegiatan ini di fokuskan pada pengumpulan data tentang manajemen pembelajaan dalam mengembangkan kemampuan sosial anak usia dini mulai dari perencanaan, pelaksanaan dan evaluasi yang dilakukan oleh guru-guru TK dalam upaya mengembangkan kemampuan sosial peserta didik, sehingga peneliti dapat langsung menganalisis dan menyimpulkan data yang telah diperoleh, kemudian peneliti tuangkan dalam temuan penelitian maupun pembahasan.Teknik wawancara yaitu dilakukan secara terstruktur. Wawancara terstruktur dilakukan setelah tercapai kedekatan dan adanya kesempatan peneliti melakukan wawancara terhadap sumber data. Peneliti menjalin keakraban terlebih dahulu dengan sumber data sebelum melakukan wawancara terstruktur. Wawancara digunakan untuk memperoleh informasi secara lengkap segala hal yang dipikirkan, direncanakan, dirasakan, dan dikerjakan terkait perencanaan, pelaksanaan dan evaluasi dalam mengembangkan kemampuan sosial anak usia dini. Ketika melakukan wawancara dengan para informan, peneliti sedapat mungkin merekam wawancara tersebut dengan menggunakan perekam suara, setelah terlebih dahulu meminta ijin kepada pihak terwawancara untuk bersedia direkam selama wawancara berlangsung. Peneliti juga selalu menyampaikan pesan kepada para informan ketika akan direkam, dengan mangatakan bahwa hasil rekaman hanya digunakan untuk kepentingan penelitian, bukan untuk dipublikasikan. Hasil wawancara yang direkam ataupun wawancara, langsung dituangkan dalam catatan lapangan dan dideskripsikan hasil analisisdalam mengembangkan kemampuan sosial anak.

Selanjutnya, studi dokumentasi dilakukan oleh peneliti dengan cara mengajukan permohonan dokumen-dokumen yang diperlukan dengan menyertakan surat penelitian, dan daftar dokumen yang diperlukan berupa RPPM, RPPH, rencana pengembangan sosial anak, dan data lainnya yang dianggap perlu. Tahap kedua yaitu kondensasi data. Dalam kegiatan ini peneliti mengidentifikasi dan menyusun data kemudian dikategorisasikan dan dilakukan pengkodean. Tahap ketiga yaitu penyajian data, peneliti lakukan dalam bentuk teks naratif dan bagan. Tahap keempat yaitu penarikan kesimpulan dan verifikasi. Dalam kegiatan ini peneliti menggunakan pendekatan emik yaitu berdasarkan kacamata informan. 


\section{HASIL DAN PEMBAHASAN}

\section{Perencanaan Pembelajaran Dalam Mengembangkan Kemampuan Sosial Anak Usia Dini}

Perencanaan merupakan kerangka berpikir yang sistematis dan penentuan dari apa yang harus dilakukan oleh seseorang. Dengan perencanaan yang baik dan matang maka suatu kegiatan akan berjalan lancar dan maksimal. Menurut Roger A.Kauffman dalam (Luluk Asmawati, 2014)mengatakan bahwa perencanaan adalah suatu proyeksi tentang apa yang diperlukan dalam rangka mencapai tujuan yang bernilai.Oleh karena itu, sebelum memulai proses pembelajaran seorang guru harus menyusun perencanaan pembelajaran yang mencakup visi, misi, tujuan, kalender pendidikan, pengembangan program tahunan pengembangan program semester, rencana pengelolaan program yang disusun dalam rencana kegiatan mingguan dan rencana kegiatan harian, menetapkan materi dan metode, serta media pembelajaran yang digunakan dalam kegiatan pembelajaran anak usia dini.

Berdasarkan data yang diperoleh peneliti di TK Amaliah Mandara Mendidoha diketahui bahwa penyusunan visi, misi dan tujuan lembaga dapat dijadikan sebagai acuan pokok untuk mengembangkan kemampuan sosial anak usia dini dalam pembelajaran sehingga untuk menjadikan peserta didik memiliki sikap sosial yang baik terhadap teman sebaya maupun pada orang tua, maka kinerja guru PAUD perlu ditingkatkan. Selain itu, dalam mengembangkan kemampuan sosial peserta didik melalui pembelajaran, seorang guru juga harus memperhatikan kalender pendidikan yakni pembelajaran dilaksanakan pada waktu pembelajaran efektif dan minggu efektif belajar, sehingga dalam satu minggu ada $5 \mathrm{kali}$ pertemuan khusus pembelajaran sosial emosional anak. Hal ini telah disusun dalam kurikulum yang di dalamnya dijelaskan bahwa setiap lingkup perkembangan masing-masing memiliki alokasi waktu yang sama dalam satu minggu. Namun dalam penyusunan program tahunan masih kurang efektif. Hal ini disebabkan karena setiap tahunnya tidak dilakukan pembaharuan yang menunjukkan tingkat pencapaian perkembangan yang sesuai dengan kenyataan di lapangan.

Dalam hal pengembangan program semester dilakukan dalam satu tahun yang memuat dua semester dan memiliki tema-tema yang berbeda. Contohnya pada semester satu terdapat beberapa tema antara lain lingkunganku, kebutuhanku, tumbuhan, dan binatang. Kemudian tema pada semester duaseperti alat komunikasi, tanah airku, alam semesta dan rekreasi. Namun penulis hanya mengambil tema "tanah airku dan alam semesta sebagai sampel peserta didik diTK AmaliahMandara Mendidoha. Pada tema yang dipilih, penulis melihat bahwa masing-maisng peserta didik telah menunjukkan pengembangan aspek sosial yang disampaikan, namun kemampuan sosial tersebut tidak cenderung ditingkatkan dalam proses kegiatan pembelajaran, akan tetapi ditingkatkan melalui pembiasaan atau dalam kegiatan inti pembelajaran. Untuk Rencana Kegiatan Mingguan (RKM) berisi kegiatankegiatan dalam rangka mencapai kemampuan yang telah direncanakan untuk satu minggu sesuai tema yang telah ditentukan. Sedangkan Rencana Kegiatan Harian (RKH) lebih diarahkan dalam kegiatan pembelajaran agar sesuai dengan tema yang telah disiapkan oleh guru. Namun dalam rencana kegiatan harian, penulis mengamati masih kurang efektif pada bagian hasil, karena pada bagian tersebut belum menunjukkan adanya keterangan antara peserta didik yang belum berkembang dan yang sudah berkembang. Sehingga dari hal tersebut, perlu diadakan pembaharuan dalam penyusunan $\mathrm{RKH}$ berikutnya dimana $\mathrm{RKH} / \mathrm{RPPH}$ ini merupakan panduan untuk perencanaan atau persiapan guru yang akan mengajar setiap tahunnya (Hadiati \& Fidrayani, 2019). Dengan demikian, perencanaan kegiatan pembelajaran dengan baik maka proses pembelajaran akan memperoleh hasil yang maksimal

(Hasnida \& Masyitoh, 2019).

Langkah selanjutnya yang dilakukan dalam merencanakan pengembangan kemampuan sosial anak usia dini adalah menetapkan materi dan metode pembelajaran. Dari hasil pengamatan dan wawancara, penulis mengetahui bahwa dalam kegiatan ini guru mengembangkan kemampuan sosial anak usia dini melalui materi pembelajaran sosial 
emosional dengan menggunakan metode pembiasaan dan bermain peran. Akan tetapi berdasarkan data yang diperoleh, materi pembelajaran yang memfokuskan kemampuan sosial tersebut perlu ditambah yaitu berupa buku karena dari pengamatan penulis pada lembar kerja anak dan buku sangat minim kaitannya dengan kemampuan sosial. Selain itu, untuk mengembangkan kemampuan sosial peserta didik tersebut, dapat digunakan alat permainan sebagai media. Akan tetapi, di TK Amaliah Mandara MendidohaDesa Ululakara sangat minim jumlah alat permainan yang disukai anak TK sehingga menyebabkan kemampuan sosialnya kurang berkembang. Oleh karena itu untuk menjaga agar kemampuan sosial peserta didik tetap berkembang baik, seorang guru harus menambah jumlah alat permainan yang disukai.

\section{Pelaksanaan Pembelajaran DalamMengembangkan Kemampuan Sosial Anak Usia Dini}

Pelaksanaan pembelajaran merupakan kegiatan belajar mengajar yang sesungguhnya dilakukan oleh guru dan sudah ada interaksi langsung dengan anak didik mengenai pokok bahasan yang diajarkan (Agus Wibowo, 2013). Oleh karena itu, proses pembelajaran tidak boleh jika hanya berhubungan dan saling berkomunikasi, sebab jika interaksi pembelajaran menoton dan membosankan, maka anak-anak tidak memiliki semangat dalam proses pembelajaran (Fadlillah, 2012). Pada tahap pelaksanaan pembelajaran di TK Amaliah Mandara Mendidoha, pembelajaran dilakukan dengan menyesuaikan rencana yang telah disusun. Dalam hal ini guru dapat mengatur kegiatan belajar agar terarah pada pembentukan sikap sosial anak. Oleh karena itu, untuk menunjang pelaksanaan kegiatan pembelajaran, guru melakukan hal-hal penting bagi peserta didiknya antara lain:

Pertama,mengelola kelas dilakukan dengan menata meja dan kursi menjadi beberapa kelompok sehingga setiap anak memiliki ruang gerak yang lebih leluasa. Setiap kelas disediakan lemari khusus untuk buku tugas anak dan rak khusus tas, sehingga peserta didik dapat belajar dan membiasakan diri untuk meletakkan barang sesuai tempatnya. Kemudian pengorganisasian peserta didik juga dilakukan dengan mengelompokkan pesertanya sesuai kebutuhan dan kelompok umur, terutama peserta didik baru. Karena seorang guru membutuhkan tenaga ekstra ketika menjadi guru kelas peserta didik baru. Kegiatan ini diamati penulis pada saat kegiatan pembelajaran berlangsung dan beberapa peserta didik tampak ada yang menangis dan bahkan tidak mau berpisah dengan ibunya. Oleh karena itu untuk mengatasi hal tersebut, guru kelas ikut serta untuk mengkondisikan pembelajaran. Namun dalam pengelolaan kelas ini terdapat beberapa kekurangan diantaranya kurangnya tenaga pendidik yang seharusnya setiap kelas memiliki dua tenaga pendidik yaitu guru kelas dan guru pendamping. Di samping itu, pihak yayasan kurang menghiraukan hal tersebut untuk diadakannya tambahan tenaga pendidik baru yang profesional.

Kedua, penyampaian materi secara sistematis. Dalam kegiatan pengembangan kemampuan sosial peserta didik dilakukan dengan menggunakan materi pembelajaran sosial emosional yang meliputi: disiplin, tanggung jawab, tolong menolong, dan kerja sama. Hal ini tertuang dalam rencana pembelajaran dan aspek tersebu tergabung menjadi satu, namun penulis hanya mengambil kegiatan pembelajaran yang menyangkut tentang perkembangan sosial saja.

Ketiga, menerapkan metode bermain peran. Dalam kegiatan ini, peserta didik dilatih untuk dapat memecahkan masalah sendiri namun tetap dengan bantuan guru kelas. Sehingga guru harus meningkatkan metodenya sebagai cara yang efektif dalam mengembangkan kemampuan sosial peserta didik. Selain itu, dengan bermain peran peserta didik juga dapat berlatih untuk mengemukakan pendapat.

Keempat, menggunakan alat peraga yang sesuai. Untuk mendukung pengembangan kemampuan sosial anak usia dini, TK Amaliah Mandara Mendidoha tersebut menggunakan alat peraga permainan itu sendiri. Namun jika mengacu pada metode bermain peran, maka alat peraga tersebut harus menyesuaikan tema yang disampaikan guru. Selain alat permainan tersebut, anak didik juga dapat menjadi peraga dalam kegiatan pembelajaran karena peserta 
didik harus tetap aktif meskipun tanpa bantuan alat permainan itu sendiri. Temuan tersebut didukung oleh pendapat Heryanti (2014)yang menyatakan bahwa metode bermain peran merupakan metode pembelajaran yang melibatkan interaksi antara dua siswa atau lebih tentang suatu topik dimana siswa memainkan peran sesuai dengan tokoh yang ia lakoni dalam hubungan sosial antar manusia setelah mendengar penjelasan guru tanpa harus mengalami latihan dan menghafal naskah sebelumnya. Hal ini juga ditegaskan oleh pendapat Wardah Anggraini (2019)yang menyatakan bahwa metode bermain peran (role playing) merupakan metode pembelajaran yang digunakan untuk meningkatkan perkembangan berbagai aspek usia dini salah satunya adalah perkembangan kognitif.
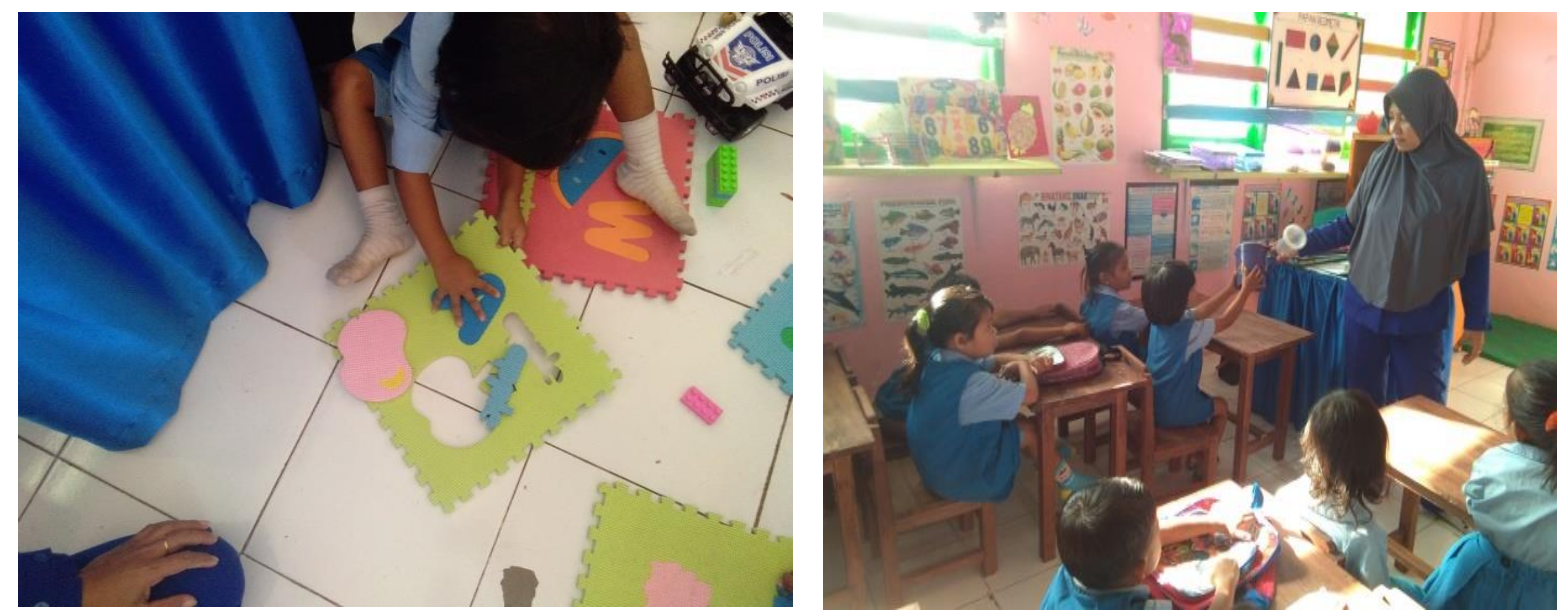

Gambar 2. Kegiatan mencocokkan pola dan huruf serta perkenalan alat peraga
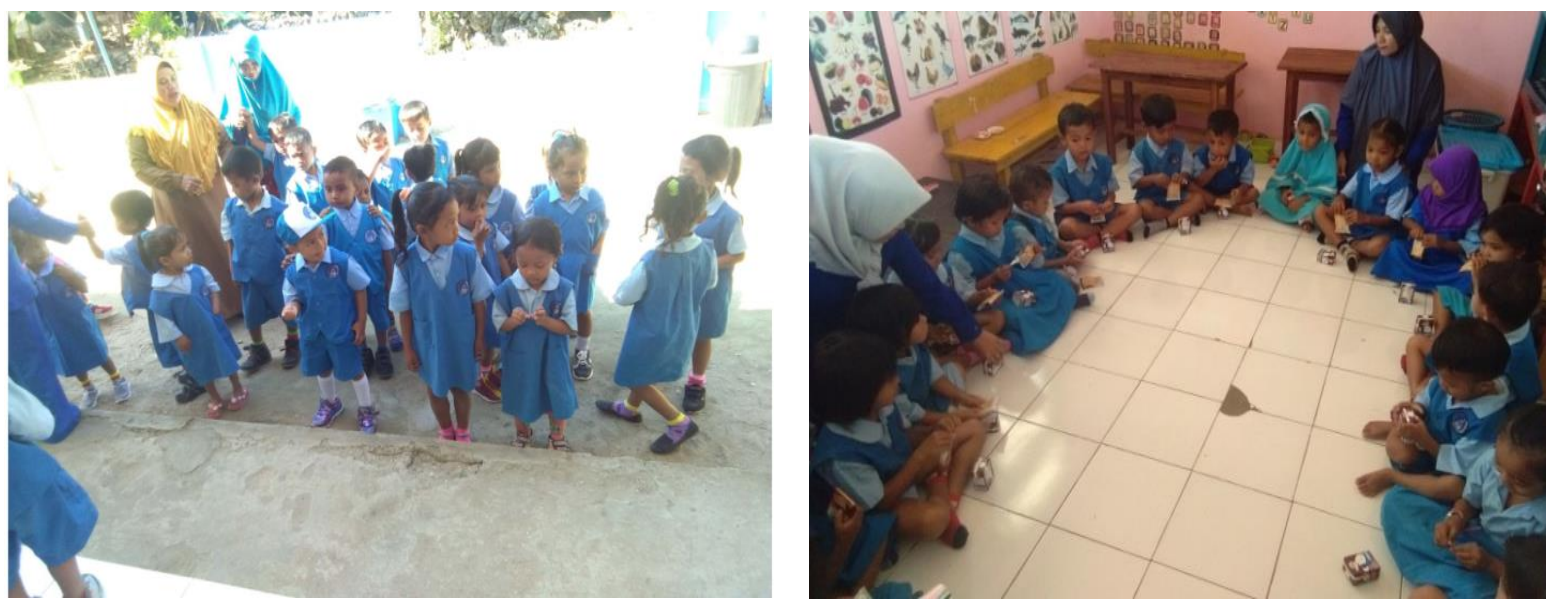

Gambar 3: Kegiatan berbaris sebelum masuk kelas (pembiasaan) dan belajar makan bersama

\section{Evaluasi Pembelajaran Dalam Mengembangkan Kemampuan Sosial Anak Usia Dini}

Evaluasi merupakan proses pengumpulan data atau informasi tentang anak yang ditujukan untuk membuat keputusan. Untuk mengetahui perkembangan kemampuan sosial peserta didik Di TK Amaliah Mandara Mendidoha Desa Ululakara, guru melakukan tiga teknik evaluasi dalam mengelola pembelajaran meliputi:

Pertama; penilaian dalam pembelajaran, guru menerapkan teknik penilaian seperti pengamatan, unjuk rasa, dan catatan anekdot untuk mengetahui perkembangan sosial anak. Evaluasi ini dilakukan pada saat seorang guru mengajar sambil melakukan evaluasi dengan mengacu pada kompetensi anak yang hendak dicapai sebagaimana yang telah dirancanag dalam perencanaan pembelajaran. Dari berbagai teknik evaluasi yang diterapkan, hanya 
pengamatan yang paling efektif dan hampir setiap hari dilakukan oleh guru terhadap kemampuan peserta didiknya. Untuk mengetahui apa yang dilakukan peserta didiknya, guru melakukan pengamatan mulai anak sampai di sekolah hingga anak pulang sekolah, baik pada saat anak bermain, bergaul, maupun berkomunikasi terhadap orang lain.

Kedua; kegiatan pelaporan perkembangan peserta didik ini dapat berupa raport dan buku induk. Pelaporan ini digunakan sebagai bentuk evaluasi dalam manajemen pembelajaran. Bentuk nyata dari pelaporan tersebut adalah laporan perkembangan belajar anak. Dalam hal ini, yang dikemukakan dalam laporan adalah perilaku dan kemampuan anak yang menggambarkan ketercapaian dalam rentang pertumbuhan dan perkembangan anak yang diperoleh dari kegiatan pelaksanaan program yang diikuti anak (Yus Anita, 2012). Pelaporan ini berbentuk raport yang ditulis oleh guru sebagai sarana komunikasi terhadap orang tua muri guna untuk mengetahui perkembangan anaknya selama mengikuti pembelajaran. Selain itu ada juga yang ditulis dalam buku induk yang digunakan sebagai arsip sekolah dan berisi tentang program yang dinilai seperti pengembangan pembiasaan. Berdasarkan tema penelitian, peneliti hanya mengambil pembahasan pada kemampuan sosial anak yang merupakan bagian dari pengembangan pembiasaan. Uraian mengenai kemampuan sosial dalam isi raport ditulis menjadi satu dengan kemampuan emosional, karena dua kemampuan ini saling berhubungan. Sehingga indikator yang dicapai juga disesuaikan dengan perangkat perencanaan pembelajaran. Berikut ini isi raport yang menunjukkan penilaian pengembangan sosial emosional:

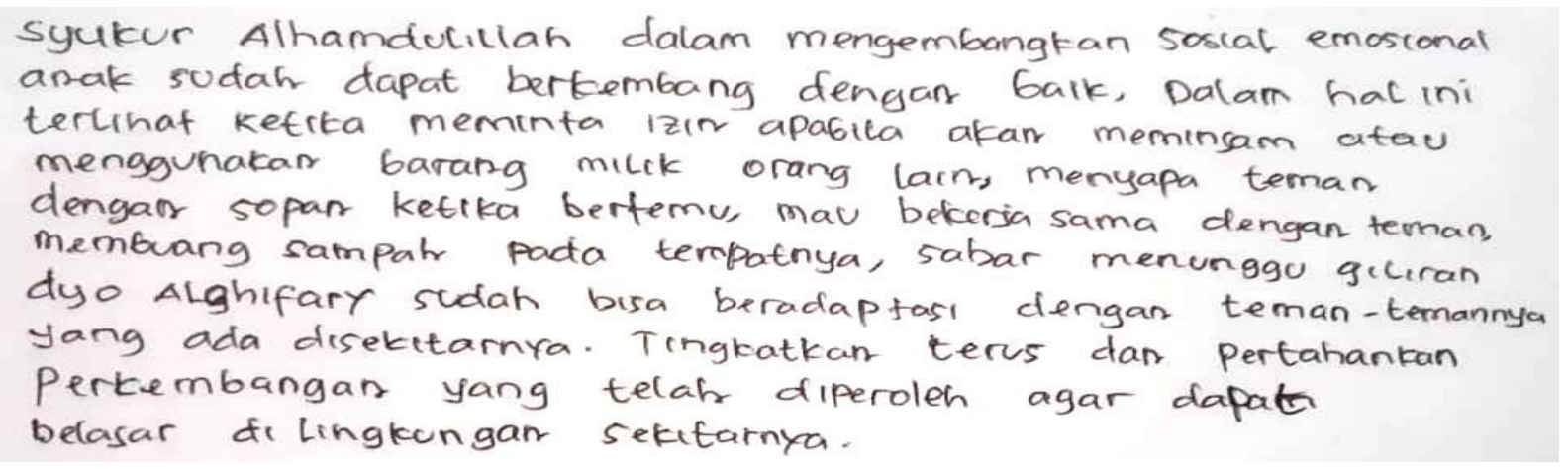

\section{Gambar 4: Isi raport pada aspek sosial emosional}

Kegiatan terakhir yang telah dilakukan dalam evaluasi pembelajaran adalah tindak lanjut dari hasil penelitian yaitu melalui beberapa langkah dalam mengevaluasi pembelajaran tersebut dapat digunakan guru untuk mengetahui sejauh mana peserta didik memehami semua materi yang telah diberikan oleh guru. Selain itu, dapat juga digunakan sebagai tolak ukur bagi guru dalam pengambilan keputusan untuk merencanakan pembelajaran berikutnya. Dengan demikian antara guru dan orang tua dapat mendiskusikan perkembangan masing-masing anak dengan mengacu pada perkembangan anak yang telah dicapai sebelumnya.Sebagaimana Damayanti et al (2018) mengatakan bahwa proses evaluasi dapat dilakukan melalui tahap perencanaan, pelaksanaan atau pencatatan, pengolahan hasil belajar, pengarsipan, dan pelaporan. Hal serupa juga dilakukan oleh Hani (2019) bahwa evaluasi pembelajaran di PAUD dapat dilakukan dengan menentukan cara evaluasi yang tepat sesuai dengan perencanaan pembelajaran. Dalam evaluasi pembelajaran yang berbentuk rating scale sebaiknya dilakukan secara keseluruhan dalam artian terkadang guru menilai dengan mensamaratakan perkembangan antara peserta didik satu dengan yang lainnya,(Agus Jatmiko, 2020). Evaluasi pembelajaran yang efektif dapat memperlihatkan berbagai kondisi dan kebutuhan pembelajaran anak usia dini yang perlu ditingkatkan (Utami et al., 2019). 


\section{SIMPULAN}

Perencanaan pembelajaran untuk mengembangkan kemampuan sosial anak usia dini disusun bersama guru-guru TK sesuai ketersediaan sarana dan prasarana belajar yang ada di sekolah. Pelaksanaannya dilakukan dengan mengelola kelas, menyampaikan materi, dan menggunakan metode serta alat peraga yang relevan. Evaluasi dalam pengelolaan pembelajaran dilakukan dengan dua tahap yaitu penilaian pembelajaran dan pelaporan perkembangan peserta didik. Penilaian pembelajaran dilaksanakan dengan teknik pengamatan dan unjuk kerja. Kemudian pelaporan perkembangan peserta didik berupa buku induk sekolah dan buku raport peserta didik sebagai sarana komunikasi antara guru dan wali murid untuk melaporkan perkembangan kemampuan sosial peserta didik selama mengikuti pembelajaran.

\section{UCAPAN TERIMA KASIH}

Terima kasih tim peneliti ucapkan kepada kepala sekolah, guru-guru TK dan staf administrasi yang telah berkontribusi dalam proses penelitian ini, dan editor serta reviewer Jurnal Obsesi: Jurnal Pendidikan Anak Usia Dini yang telah memberikan masukan dalam penulisan artikel ini sehingga dapat dipublikasikan.

\section{DAFTAR PUSTAKA}

Agus Jatmiko, Eti Hadiati, M. O. (2020). Penerapan Evaluasi Pembelajaran Anak Usia Dini. Al Athfaal. Jurnal Ilmiah Pendidikan Anak Usia Dini, 3(1), 83-97.

Agus Wibowo. (2013). Manajemen Pendidikan Karakter di Sekolah, Yogyakarta: Pustaka Pelajar.

Ahmad Denico. (2018). Pengelolaan Pembelajaran Pendidikan Anak Usia Dini di KB Cerdas Kecamatan Batu Hampar Kabupaten Rokan Hilir. Jurnal Pendidikan Islam Anak Usia Dini. Vo. 01 No. 02.

Ahmad Susanto. (2012). Perkembangan Anak Usia Dini: Pengantar dalam Berbagai Aspeknya. Jakarta: Kencana.

Akhmad Muhaimin Azzet. (2010). Mengembangkan Kecerdasan Sosial bagi Anak. Jogjakarta: Katahati.

Damayanti, E., Hartika, A. S., \& H. (2018). Manajemen Penilaian PAUD di TK Citra Semata. MANAEKE Indonesian Journal of Early Childhood Education, 1.

Dewi, K. (2017). Pentingnya Media Pembelajaran untuk Anak Usia Dini. Raudhatul Athfal, 1. https://doi.org/https://doi.org/10.19109/ra.v1i1.1489.

Dyah Fifin Fatimah, N. R. (2016). Pola Pengelolaan Pendidikan Anak Usia Dini di PAUD Ceria Gondangsari Jawa Tengah. Manageria: Jurnal Manajemen Pendidikan Islam. Volume 1, Nomor 2,.

Fadlillah, M. (2012). Desain Pembelajaran PAUD: Tinjauan Teoretik E Praktik, Jogjakarta: ARRUZZ MEDIA.

Hadiati, E., \& Fidrayani. (2019). Manajemen Pembelajaran Pendidikan Anak Usia Dini. AL ATHFAAL: Jurnal Ilmiah Pendidikan Anak Usia Dini, 2(1), 69-78.

Hani, A. A. (2019). Evaluasi Pembelajaran Pada PAUD. Care, 7(1), 52-56.

Hasnida \& Masyitoh. (2019). Perencanaan Pembelajaran Anak Usia Dini (Studi Pengintegrasian Kurikulum 2013 Paud Dengan Aik Di Taman Kanak-Kanak Aisyiyah 4 Tebet Timur, Jakarta Selatan). Jurnal Emanasi, Jurnal Ilmu Keislaman Dan Sosial . Vol 2, No. 1.

Heryanti Putri Tarmizi. (2014). Metode Pembelajaran Sosiodrama. Metode Pembelajaran Sosiodrama", http://heryantiputritarmizi.blogspot.com/2013/09/heryantimetodepembelajaran-sosiodrama.html?m=1, diakses 21 November 2020.

Kusbudiah, Y. (2014). Pengelolaan Pembelajaran Di RA/TK/PAUD Sebagai Upaya Mengoptimalkan Pencapaian Perkembangan anak Usia Dini. Diakses Pada Http://Bdkbandung.Kemenag.Go.Id/Jurnal/ 276-Pengelolaan-Pembelajaran-Di-Ra-TkpaudSebagai-Upaya-Mengoptimalkan-Pencapaian-Perkembangan-Anak-Usia-Dini Tanggal 16 
April 2017.

Luluk Asmawati. (2014). Perencanaan Pembelajaran PAUD, Bandung: PT Remaja Rosdakarya.

Miles, M. B, Huberman, A. M, dan Saldana, J. (2014). Qualitative Data Analysis, A Methods Sourcebook, Edition 3. USA: Sage Publications. Terjemahan Tjetjep Rohindi Rohidi, UI-Press.

Munawaroh, H. (2017). Pengembangan Model Pembelajaran dengan Permainan Tradisional Engklek Sebagai Sarana Stimulasi Perkembangan Anak Usia Dini. Obsesi, 1(2), 86-96. https://doi.org/10.31004/obsesi.v1i2.19.

Rozalena, M. K. (2017). Pengelolaan Pembelajaran PAUD Dalam Mengembangkan Potensi Anak Usia Dini. Jurnal Manajemen, Kepemimpinan, Dan Supervisi Pendidikan, Volume 2. https:/ / doi.org/10.31851/jmksp.v2i1.1155

Sugiyono. (2017). Metode Penelitian Kuantitatif, Kualitatif, dan RED. Bandung: Alfabeta, CV.

Suharni. (2019). Manajemen Pendidikan Anak Usia Dini Pada PAUD Bintang Rabbani Pekanbaru. Jurnal Ilmiah Potensia, Vol. 4 (1), 1-5.

Suharti. (2018). Manajemen Pendidikan Anak Usia Dini (PAUD) dalam Rangka Meningkatkan Mutu Pembelajaran (Studi pada PAUD Negeri Pembina Curup Pertiwi Kabupaten Rajang Lebong). TADBIR: Jurnal Studi Manajemen Pendidikan, 51-70.

Usman, H \& Akbar, P. S. (2017). Metodologi Penelitian Sosial. Edisi Ketiga. Jakarta: Bumi Aksara.

Utami, W. Y. D., Jamaris, M., \& Meilanie, S. M. (2019). Evaluasi Program Pengelolaan Lembaga PAUD di Kabupaten Serang. Jurnal Obsesi : Jurnal Pendidikan Anak Usia Dini, 4(1), 67. https:// doi.org/10.31004/obsesi.v4i1.259

Wardah Anggraini, A. D. P. (2019). Penerapan Metode Bermain Peran (Role Playing) dalam Mengembangkan Kognitif Anak Usia 5-6 Tahun. J(JECED) Journal of Early Childhood Education and Development.

Yus Anita. (2012). Penilaian Perkembangan Belajar Anak: Taman Kanak-Kanak. Jakarta Kencana Prenada Media Group, Cet. 2.

Zubaidi, M. (2020). Profesionalisme Guru dan Efektifitas Pembelajaran pada Pendidikan Anak Usia Dini. Obsesi, 4(2). https://doi.org/10.31004/obsesi.v4i2.505. 